\title{
Fifty years ago: the Vaiont night
}

\author{
Valerio Spagna
}

\author{
Article history \\ Received December 16, 2011; accepted February 7, 2012. \\ Subject classification: \\ Environmental risk, Vaiont disaster, Landslide, Flood, First-aid teams.
}

\begin{abstract}
A geologist at the beginning of his career in the early 1960's was a teacher of mineralogy and geology at the Agordo "Follador" Mining Institute in the Dolomites area. It was 50 years ago now when he observed the building of the Vaiont dam, and here he tells us of the night of October 9, 1963, when he rushed to the Piave Valley together with the first-aid teams, to confront the remains of Longarone. Did the dam collapse? Everybody thinks so, but the moon was not shining enough to allow an understanding of what had happened. It was only the first faint light of dawn that revealed that the dam was still standing: it was only edged by the water, from the shaping of the tremendous wave that was raised by the Mount Toc landslide when it entered the basin at $100 \mathrm{~km} / \mathrm{h}$. The dam edge contributed to the projection of the wave onto the opposite slopes, where once the water mass was released from the narrow Vaiont canyon, it raised solidly into the air, grazing the Casso village and precipitated as a massive block on the Longarone area. Everybody looked upwards with hate and despair, at the residual water streamlets that were overflowing along the concrete wall of the dam. Over the white bare esplanade people appeared extremely small. Pitiful people, gathered around the bodies wrenched from the devastated houses, denuded and buried in the mud.
\end{abstract}

\section{Introduction}

As we approach 50 years after the disaster of Vaiont, the scientific community has never stopped the thorough study of the combined causes and the final mechanisms of the terrible landslide of October 9, 1963, that brought death and destruction to the villages of Longarone, Erto and Casso, and that ruined a community of over 2,000 inhabitants.

The scientists who carried out the most serious studies after that tragedy to provide the most suitable means to prevent such disasters in populated areas could not express emotion when they had to evaluate methods and to design schemes for future public works in front of the elements of Nature.

By reporting this personal testimony of that night in Longarone, the emotion of the Author is intended to remind us of the necessary link between the respect for human conditions and scientific knowledge, like a request to keep them improving.

\section{The testimony of geologist Valerio Spagna, who rushed to the disaster site}

That quiet evening, while waiting for our child to go to sleep, was the beginning of the most dramatic night that I have ever lived [Valerio Spagna 2010]. Suddenly, at a quarter to eleven, the electricity cut out for a few minutes. Then the silence was broken by the shrilling of the sirens of the firemen. I got up and followed my instinct towards something I did not know, but that was certainly serious. I got into my car, still dressed in the greyish suit and tie I used to wear for teaching at the school. I greeted Leda, who was also wondering about the situation, and worrying for the baby's sleep. Among the few cars on the "Agordina" national road, I heard voices talking about a dam that had collapsed. I followed them along the valley of the Cordevole river.

I then drove through Belluno, and arrived at the Ponte in the Alps, as if attracted by a strong magnet. The road was blocked by the police: nobody could have access to the Piave valley. By now it was clear that the Vaiont dam had collapsed and had flooded the whole valley.

I wanted to reach the dam, which I knew well because I had seen it growing from the foundations to the crest at $262 \mathrm{~m}$ above the valley floor. I drove back to Agordo, and from there I took the road leading to the Passo Duran, up to $1,600 \mathrm{~m}$, and down into the Zoldo valley.

Now alone as I was driving down towards the Piave valley in front of Longarone, I felt surrounded by a tragic atmosphere and my head was aching. I then heard voices coming from the Longarone houses set above. Along the roadside, men were looking down into the valley. I parked the car and joined them.

They were reviewing the familiar houses, but only by remembering their places according to their owners' names; a painful list. "The Julia workshop?" "Nija, nija!" answered a choir. "Where Nani lived?" "Nija, nija!" "The postman's house?" "Nija, nija!" The afflicted litany went on. My throat was tightened by those "Nothing, nothing!"

At one o'clock, a row of miners' lamps appeared, held 


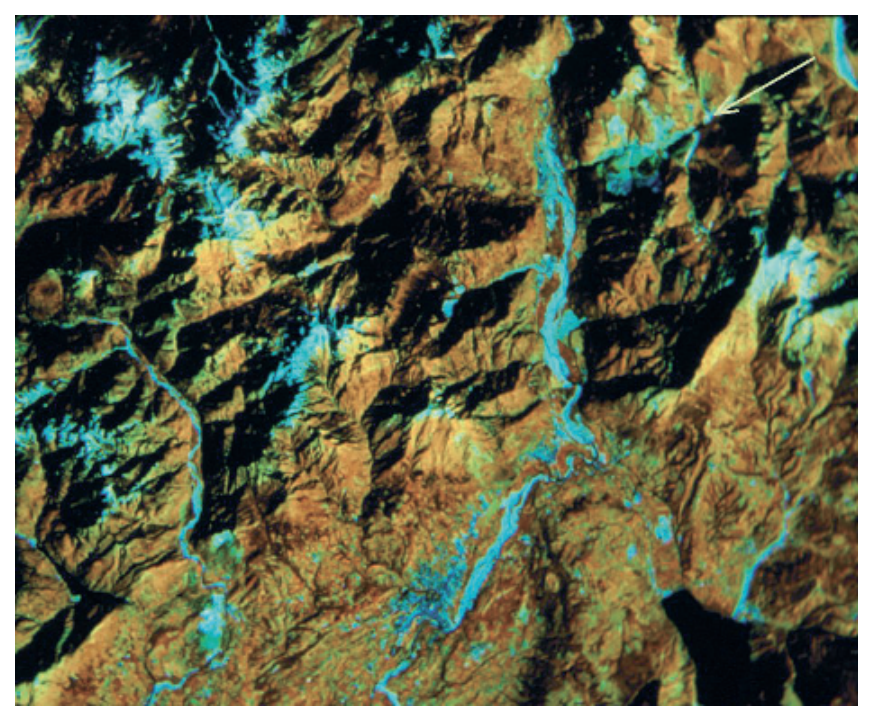

Figure 1. Satellite image of the Vaiont Valley, and the tributary torrent of the Piave River Basin.

by the Alpinists, carrying on their shoulders a coil of rope. Without a word they walked past, bound together by a long cord, the noise of their boots on the detritus spread on the path rose up on the background of screams and cries.

At that stage, we all looked in the direction of the dam with a mixture of fear and hate. On this mild autumn night, the sky behind the Vaiont valley section was brightened by the moonshine, showing a ' $V$ ' profile so deep that it suggested that the dam was no longer there. When the moon outlined Mount Toc, we realized that what we thought was a piece of sky was nothing else than the bright reflection of the water, still overflowing the basin.

Only with the first light of dawn did we see clearly the gray dome of the concrete dam wall, with the residual fall of water. The bottom of the Piave Valley appeared now like a white desert plain, without any houses, completely bare, as well as the hill where the village of Pirago once stood, recognizable now only by the bell tower of the hamlet that had miraculously escaped the wave that had swept everything around.

Gray bodies, completely undressed by the raging waters, with the hands of compassionate women trying to put together the dislocated limbs. An atmosphere of total defeat, and a sense of uselessness on behalf of the rescuers, who could do nothing

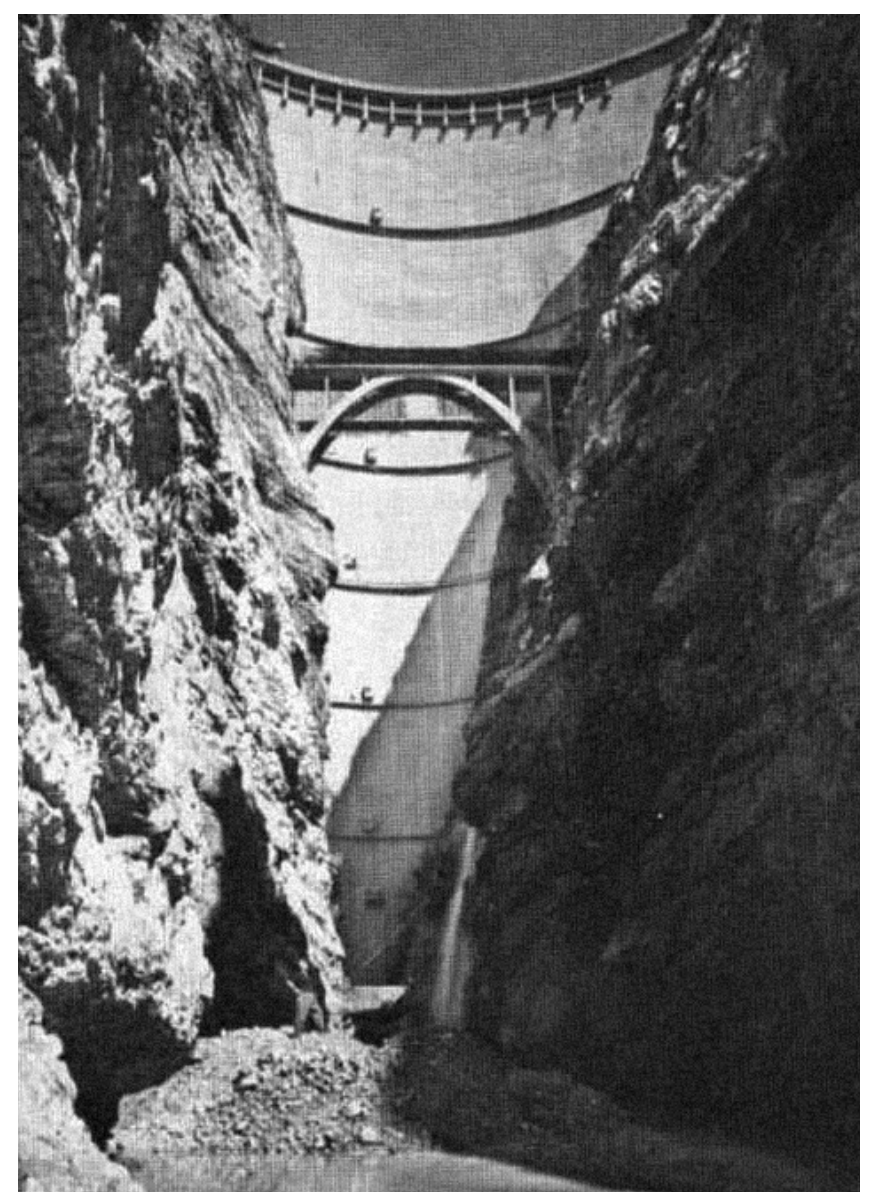

Figure 2. The wall of the arch-dam rising to $262 \mathrm{~m}$ from the bottom of the Vaiont canyon valley.

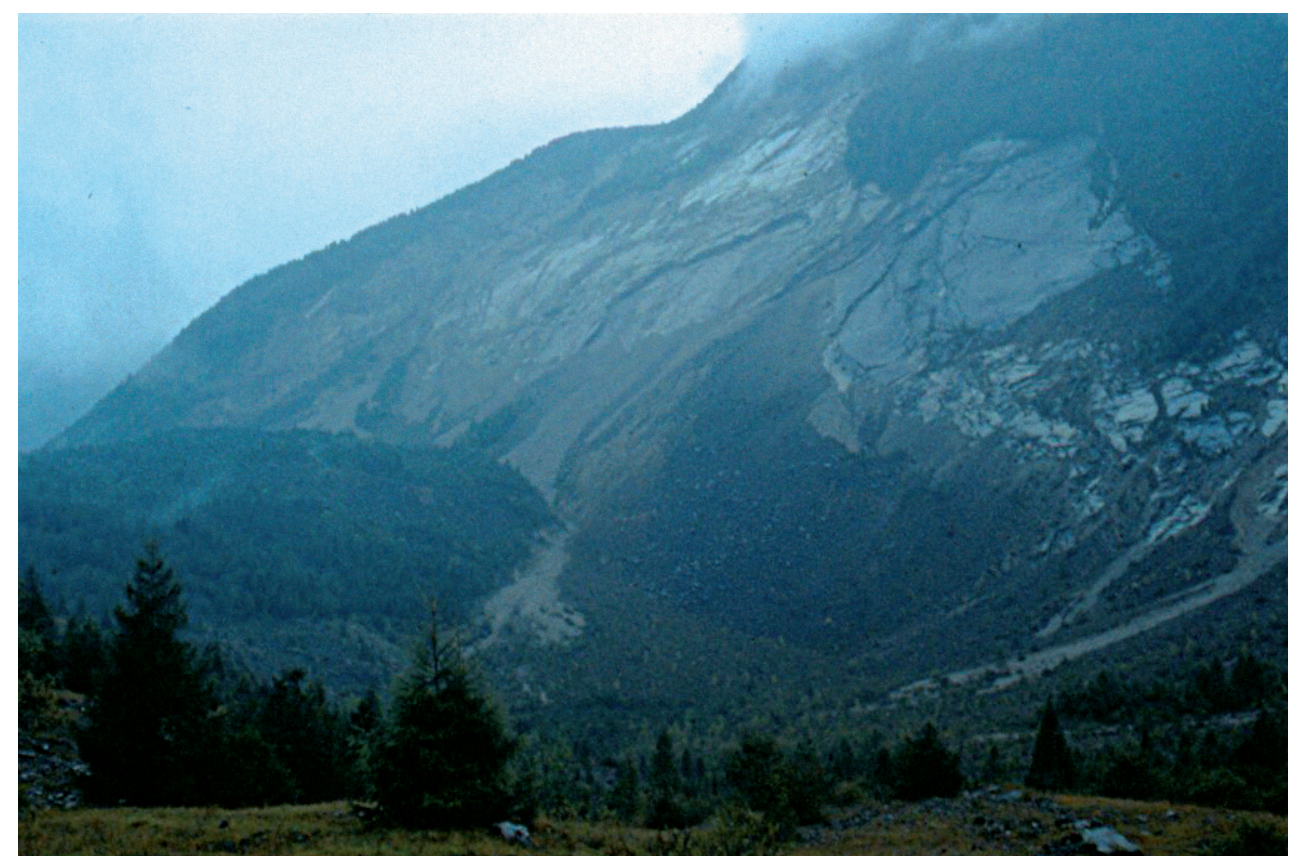

Figure 3. The present rock mass landslide. but make helpless movements, holding their heads between their hands. Everywhere a sea of mud. The stones embedded in the mud made it look like a lava flow. From that loose surface emerged only entire bodies, of both 
adults and children, naked, or with their clothes covered in the mud.

The large plain through which Longarone had expanded appeared like a huge desert, a hallucinatory landscape unknown for the bottom of an Alpine valley. The human forms moving without knowing where to go, and the men carrying out the rescue, helpless, and appearing very small.

A last distressed look from Pirago to the valley. My car was parked by a truck with drop sides that was being loaded with the bodies as they were progressively extracted from the mud. I took the Passo Duran road, and went straight to the school without changing my clothes.

The radio gave the news of the disaster. The principal of the school had gathered the students and teachers in the square in front of the Institute. I felt his words inappropriate and out of the place, because he was not conscious of the extent of the catastrophe. I was horrified when he considered the human cost, as happens in the mines, as the usual tribute to the development of the human condition (!).

I closed my eyes and saw the human condition in the expanse of mud in Longarone that I had just left, and as soon as I opened my eyes again I saw the students of the Third class gathered around the reddish hair of Dal Molin, whose face was convulsed. His eyes were swollen, but they did not cry: his family had disappeared entirely.

In the following days, other victims were found in the Piave valley, and even further downstream near Feltre. On a bend in the river near Santa Giustina Bellunese, the rescuers found a body imprisoned in a tangle of branches two meters above the river bank. This shows how high the wave had been when it was reversed by Vaiont Lake, and how powerful its destructive capacity had been, with such effects nearly 30 miles downstream.

For several weeks the pages of the newspapers were overflowing with the event. In the months before the Vaiont landslide, there had been continuous and suspicious movements, but public opinion had not be informed because a very important financial operation was on the way to being settled: the sale of the private hydroelectric power plants to ENEL, the new Agency created to nationalize the electricity throughout Italy. The plan of the

Digoman arch dam on the Cordevole River that would have formed a new lake upstream of the Alleghe village was abandoned. Even today, in front of the village of Laste, there are still some concrete blocks on the left shoulder, as a warning to the Italian dam builders to stifle their pride. In those years, the Kariba Dam on the Zambesi river was considered an emblem of Italian engineering throughout the world.

As a countrepoint, the famous writer Dino Buzzati, a lover of the Dolomites, wrote a heartfelt article in the "Corriere della Sera", the main national newspaper [Buzzati 1963]. He concluded his article about Cruel Nature with that cry: "The mount that broke and spread death is one of my life mounts, the profile of which is engraved in my mind and will stay there forever. The reason why the 
writer has a dry throat and cannot find the right words. The words of disbelief, dismay, anger, crying, mourning, remain inside him, with their cruel weight".

He did not want then to see that it was human cruelty, ignorance, and limits that had let loose this Nature!

"Keeping a diary and writing in his late years one's memoires should be a duty assigned by the state; the materials stored after three or four generations would have a priceless value: many historical and psychological problems that beset humanity would be solved".

(Translation from Giuseppe Tomasi di Lampedusa, Racconti, 1961).

\section{Conclusions}

The geological and geotechnical model that the enormity of this Vaiont event revealed to scientists enlarged the field of scientific knowledge of the dimensions and mode of evolution of slope dynamics, and this is now integrated into the most advanced theories of landslide classification. However, such major environment disasters make us always more aware that knowledge must precede facts, and even in front of the most painful events, human participation, consciousness and professional ethics must be the fundamental attitude of the geologist in providing contributions to basic scientific and technical knowledge in the design of large public works.

Since that tragic day, now 50 years ago, many other disasters have occurred across our rugged territory. Certainly not all of the disasters might have been predicted, but most of them have recurred cyclically and continuously, and not only in relation to large civil constructions. Instead, we have found ourselves in circumstances in which even small constructions have challenged "the limits of the safe territory", because they have been built around sensitive natural elements, such as river banks, slopes, mines, large slopes of roads and railway infrastructure, mostly by following imprudent directives in the planning. Very often this was done with the endorsement of valuable professional expertise, but without proper geological-hydraulic or geological-technical evaluation, both in the general framework in which such interventions have fallen, and also in the details of their implementation.

The memory brings us back to a ruthless and rhythmic list, from northern to southern Italy: 1966: the flood of Florence, the flood of the Belluno area, the breaking of the murazzi, the walls placed in defense of the Lagoon of Venice; 1968: the flood of Strona Valley and Biella, Piedmont; 1970: the event of Genoa and the Bisagno stream; 1977: the floods of Canavese and Val d'Ossola, Piedmont; 1978: the rail disaster of the train "Freccia della Laguna" between Bologna and Florence; 1982: the "Barducci" landslide in Ancona; 1985: the landslide of the land- fill mining of Stava, with 290 victims in Tesero, in Trentino; 1987: the Val Pola landslide, in Valtellina, Lombardy; 1994: the flood in Val Tanaro, Piedmont; 1998: the landslides in the Sarno Valley, Campania; 2000: the flood in the tourist village of Soverato, Calabria; 2009: the landslide of "Cancia" in Borca di Cadore, Veneto;... and this list is certainly incomplete.

Certainly the situation has improved, both with the more effective instruments of control and the quality of prevention studies. As an example: there is now the obligation to draw up a detailed map of the "suitability of the territory" for the planning instruments required, such as in the Veneto Region for municipal projects.

However, disasters continue to follow one after another, relentlessly (2009: the Giampilieri event in Messina; 2011: the disasters of Cinque Terre and Lunigiana; and always more...). All of the events have also worsened in recent decades, because of the buildings that were constructed along the rivers and streams. This situation imposes a duty to do more; not only a duty in the technical sense for designers and planners, but also a duty for all citizens and administrators, who are often slow to recognize their indispensable role of participation and control.

The birth of a new ethical awareness in the practice and research on Earth Sciences has manifested itself in the successfully Geoitalia 2011 Conference that was held in Turin. For all of us, this is an encouraging sign.

\section{References}

Buzzati, D. (1963). Natura crudele, In: Corriere della Sera, 11 Ottobre 1963.

Spagna, V. (2010). Il nonno si racconta. Edizioni Imprimitur, Padova (English translation: Hélène Berta Ageron).

Tomasi di Lampedusa, G. (1961). Racconti; consulted edition: Milano, Feltrinelli, 1988.

Corresponding author: Valerio Spagna,

Via Bartolomeo Cristofori 20, 35137 Padova, Italy; email: vspagna@inwind.it.

(C) 2012 by the Istituto Nazionale di Geofisica e Vulcanologia. All rights reserved. 